\title{
Interactions of maize and Italian ryegrass in a living mulch system: (2) Nitrogen and water dynamics
}

\author{
Markus Liedgens ${ }^{1,3}$, Emmanuel Frossard ${ }^{1} \&$ Walter Richner ${ }^{2}$ \\ ${ }^{1}$ ETH Zürich, Institute of Plant Sciences, FEL, CH-8315 Lindau, Switzerland. ${ }^{2}$ FAL, Swiss Federal Research \\ Station for Agroecology and Agriculture, Reckenholzstrasse 191, CH-8046 Zurich, Switzerland. ${ }^{3}$ Corresponding \\ author*
}

Received 13 July 2003. Accepted in revised form 3 October 2003

Key words: living mulch, Lolium multiflorum Lam., nitrogen dynamics, water dynamics, Zea mays L.

\begin{abstract}
Water and nitrogen availability may limit the growth of the main crop competing with a cover crop in a living mulch system. Some aspects of the dynamics of water (soil water content and deep percolation) and nitrogen (concentration in soil solution and leachate) were studied in maize (Zea mays L.) sown into a bare soil (BS, conventional cropping) or into a living Italian ryegrass (Lolium multiflorum Lam.) mulch (LM) during three years. Eight lysimeters ( 1.0 by $1.0 \mathrm{~m}$ square surface area and $1.1 \mathrm{~m}$ deep) with ceramic suction cups, TDR probes and a drainage pipe were used each. In LM a $0.3 \mathrm{~m}$ wide strip was kept free of grass around the maize row. The living mulch reduced the soil water content between 0.3 and $0.9 \mathrm{~m}$ soil depth, which remained lower even after intense rainfall. Deep percolation over the entire maize crop season was at least $40 \%$ lower in the LM compared to the BS treatment. In LM the nitrate concentrations in the soil solution and in the leachate (usually $<10 \mathrm{mg} \mathrm{L}^{-1}$ ) were very low. In BS the nitrate concentration in the leachate reached as much as $70 \mathrm{mg} \mathrm{L}^{-1}$. Losses of $\mathrm{N}$ in LM did not reach $1 \%$ of the values observed in BS. Reduced water and $\mathrm{N}$ availability in LM contribute to explain the decrease in growth and yield of the maize plants, and are in good agreement with the dense root system developed in this cropping system as compared to BS. The challenge for the development of living mulch systems is to improve the uptake of water and nitrogen by the roots of the main crop in a competitive environment without affecting the capacity of the cover crop to prevent $\mathrm{N}$ losses by leaching.
\end{abstract}

Abbreviations: a.s.l. - above sea level; BS - maize plants sown in a bare soil; DAP - days after planting; ETP potential evapotranspiration; GDD - growing degree days; LM - maize plants sown into a living Italian ryegrass mulch; $\mathrm{N}$ - nitrogen; $\left[\mathrm{NH}_{4}^{+}\right]-\mathrm{L}-$ ammonium concentration in the leachate; $\left[\mathrm{NH}_{4}^{+}\right]-\mathrm{SS}$ - ammonium concentration in the soil solution; $\left[\mathrm{NO}_{3}-\right]-\mathrm{L}$ - nitrate concentration in the leachate; $\left[\mathrm{NO}_{3}-\right]-\mathrm{SS}-$ ammonium concentration in the soil solution; TDR - time domain reflectometry.

\section{Introduction}

Living mulch cropping systems were defined as "... mixed cropping system, in which one partner acts chiefly as a live soil cover for a considerable part of the life cycle of the main crop." (Feil and Liedgens, 2001) The continuous soil cover provided by the living mulch is a good strategy for reducing soil erosion

\footnotetext{
*FAX No: +41-52-3549119.

E-mail: markus.liedgens@ipw.agrl.ethz.ch
}

(Kurtz et al., 1946, 1952). Living mulches are also able to reduce the losses of $\mathrm{N}$ by leaching as the soil mineral $\mathrm{N}$, its concentration in the leachate (Rasse et al., 1999) and the leachate volumes (Kaluli et al., 1999) are reduced. Other potential benefits of living mulches are the improved soil structure due to the organic matter input by the cover crop (Duda et al., 2003) and the aggregation effect of roots (Perin et al., 2002), the suppression of weeds (Teasdale, 1996) and 
more efficient self-regulation of pests and diseases (Ntahimpera et al., 1998; Rämert, 1996).

Much of the research on living mulch systems has focused on maize (Zea mays L.) as the main crop, mainly in temperate climate regions (Garibay et al., 1997; Martin et al., 1999), where late sowing in spring, slow early plant growth and wide spacing between plant rows are responsible for long periods of missing or insufficient protection of the soil surface of maize crops in conventional tillage systems. In Swiss agriculture these problems are relevant because of the hilly landscape and intense precipitation. Under these conditions the use of cover crops killed by frost or herbicide before the maize crop season almost completely prevented soil loss (Rüttimann, 2001). Even though losses of pesticides by run-off have also been reduced, their control was unsatisfactory. Furthermore, dead mulches are less effective in controlling weeds than is a living mulch (Weston, 1996).

In regions in which stock farming and crop production are closely integrated the use of existing grass swards as living mulches for the cultivation of maize has been proposed (Biegler et al., 1995, Box et al., 1980). In such cropping systems, productive grasses such as Italian ryegrass (Lolium multiflorum Lam.) provide protection to the soil before, during and after the maize crop season as well as high yields of grass in the spring and a pasture for grazing in the autumn (Robertson et al., 1976; Sato et al., 1999).

However, the living mulch may also compete with the maize crop, leading to smaller yields (De Haan et al., 1994; Enache and Ilnicki, 1990; Garibay et al., 1997; Robertson et al., 1976; Zemenchik et al., 2000; Liedgens et al., 2003). Shoot competition for light may occur, but it can be prevented by correct timing of chemical and/or mechanical control of the cover crop. Interactions between the main and the cover crop in a living mulch system are usually attributed to competition for water and nitrogen. Irrigation improves the yields of maize cultivated in living mulches but cannot prevent all yield losses (Adams et al., 1970; Box et al., 1980; Carreker et al., 1972; Eberlein et al., 1992; Heyland and Werner, 1988; Robertson et al., 1976). The effect of an increased supply of nitrogen on the yield of maize in living mulch systems is well documented (De Haan et al., 1994; Garibay et al., 1997; Kurtz et al., 1952; Robertson et al., 1976). Especially when grass species are used as cover crops considerable amounts of nitrogen may be required by the living mulch: in living mulches of Festuca elatior var. arundinaceae (Carreker et al., 1972), Lolium multiflorum Lam. (Garibay et al., 1997) and Festuca arundinaceae Schreb. (Wilkinson et al., 1987) 224, 250 and $290 \mathrm{~kg} \mathrm{~N}^{-1}$ were required, respectively, to achieve adequate maize yields.

The competition between the maize and cover crops for nitrogen and water in living mulches is well documented. However, the availability of water and nitrogen changes over time and space, and we know very little about this subject in living mulches. For this reason we studied the dynamics of water (soil water content and deep percolation) and nitrogen (nitrate and ammonium concentrations in the soil solution and in the leachate) of maize sown either into a bare soil (BS), which represents a conventional maize cropping system, or into a living Italian ryegrass mulch (LM), for three seasons. The results of the water and nitrogen dynamics will be linked to shoot and root data sets sampled in the same experiments and published in a companion report (Liedgens et al., 2003).

\section{Materials and methods}

A lysimeter facility (Liedgens et al., 2000) located at the Experimental Field Station of the Institute of Plant Sciences, Swiss Federal Institute of Technology (ETH Zurich), Lindau was used for the present study. A detailed description of the experiment was already given by Liedgens et al. (2003). Each lysimeter had a 1.0 by $1.0 \mathrm{~m}$ square surface area and a soil depth of $1.1 \mathrm{~m}$. The soil in the lysimeters was a slightly alkaline ( $\mathrm{pH} 7.2$ to 7.5 ) sandy loam with a low content of organic matter (3.0 to $3.5 \%$ ).

At the beginning of each experimental season, in autumn, Italian ryegrass (Lolium multiflorum Lam. cv Lipo) was sown in four lysimeters followed by maize (Zea mays L. cv Atlet; FAO maturity rating 250; KWS, Einbeck, Germany), which was sown in spring; the maize was harvested the following autumn. Four additional lysimeters had no plant cover until maize sowing (bare soil plots). The lysimeters were used for one season and left without vegetation for one year before being used again. Table 1 gives an overview of sowing and harvest dates of ryegrass and maize and the dates of maize anthesis in the three experimental seasons.

One maize row with 7 plants $\mathrm{m}^{-2}$ was sown in the center of each lysimeter. Maize was sown in the ryegrass plots in a mechanically killed and manually tilled grass band $(0.3 \mathrm{~m}$ wide $)$ in the center of the lysimeters. The bare soil plots were tilled manually to a 
Table 1. Dates of sowing and harvest of Italian ryegrass and maize and of maize anthesis in the three experimental seasons

\begin{tabular}{|c|c|c|c|c|c|c|c|}
\hline \multirow[t]{2}{*}{ Season } & \multicolumn{2}{|c|}{ Sowing } & \multirow[t]{2}{*}{ Maize anthesis } & \multicolumn{2}{|c|}{ Ryegrass harvest } & \multirow[b]{2}{*}{$3^{\text {rd }}$} & \multirow[t]{2}{*}{ Final harvest ${ }^{\mathrm{a}}$} \\
\hline & Ryegrass & Maize & & $1^{\text {st }}$ & $2^{\text {nd }}$ & & \\
\hline $93 / 94$ & 24.09 .93 & 11.05 .94 & 31.07 .94 & 02.06 .94 & 20.06 .94 & 06.07 .94 & 16.09 .94 \\
\hline $94 / 95$ & 02.10 .94 & 16.05 .95 & 06.08 .95 & 08.06 .95 & 26.06 .95 & - & 02.10 .95 \\
\hline $95 / 96$ & 10.10 .95 & 20.05 .96 & 08.08 .96 & 10.06 .96 & 27.06 .96 & - & 30.09 .96 \\
\hline
\end{tabular}

${ }^{\mathrm{a}}$ Ryegrass and maize

depth of $0.05 \mathrm{~m}$ before sowing the maize. Neighboring plant rows were simulated with shading screens at the edges of the lysimeters, parallel to the rows of maize.

All plots were fertilized with $110 \mathrm{~kg} \mathrm{~N} \mathrm{ha}{ }^{-1}$ (FAL/RAC, 2001) as ammonium nitrate placed in the maize row. Nitrogen fertilizer was applied as follows: $50 \mathrm{~kg} \mathrm{~N} \mathrm{ha}^{-1}$ at planting and the rest when the plants had two fully expanded leaves. Other nutrients were broadcast when maize was planted: $42 \mathrm{~kg} \mathrm{ha}^{-1} \mathrm{P}$, $240 \mathrm{~kg} \mathrm{ha}^{-1} \mathrm{~K}, 17 \mathrm{~kg} \mathrm{ha}^{-1} \mathrm{Mg}, 61 \mathrm{~kg} \mathrm{ha}^{-1} \mathrm{Ca}$ and $26 \mathrm{~kg} \mathrm{ha}^{-1} \mathrm{~S}$. To avoid serious drought damages, irrigation was carried out whenever the readings of tensiometers, installed at a soil depth of $0.3 \mathrm{~m}$, fell below $-80 \mathrm{kPa}$.

Harvested ryegrass and maize plants were dried for at least $48 \mathrm{~h}$ at $80^{\circ} \mathrm{C}$ and their dry weights determined. The maize samples were separated into grains and stover before the measurement of dry weight. The dry ryegrass and maize stover samples were ground successively with mills with a 3-mm (Wolf Mühle, Wien, Austria) and 1-mm sieve (Cyclotec Tecator 1093 Mill, Tecator AB, Höganäs, Sweden). The dry maize grain samples were ground once with an A 10 mill (Janke and Kunkel Labortechnik, Staufen i. Br., Germany). All grounded samples were then analyzed for total $\mathrm{N}$ with a LECO CHN-1000 auto analyzer (LECO Corporation, St. Joseph, MI, USA).

When the lysimeters were filled with soil bifilar time domain reflectometry (TDR) probes $(0.3 \mathrm{~m}$ long) were installed horizontally at depths of $0.30,0.60$ and $0.90 \mathrm{~m}$ for measuring the volumetric soil water content. To quantify the volumetric soil water content in the top soil, two TDR probes were installed vertically in each lysimeter after the maize emergence in 1995 and 1996. One probe was placed in the maize row and one $0.3 \mathrm{~m}$ away from it, the latter in the live cover crop strip in the LM plots. The TDR measurements were performed twice a week in 1994, 1995, and at the beginning of the growth season of maize in 1996. Due to a delay in receiving the equipment in 1994 it was not possible to make the TDR measurements before 51 days after planting (DAP). The graphic representation of the time taken for an electromagnetic pulse to travel between the two transmission lines of the bifilar TDR probe, as measured with a Tektronix Cable Tester (Tektronix Inc., Beaverton, Oregon, USA) was evaluated in the laboratory, and the conversion to volumetric soil water contents was made with the calibration equation proposed by Topp et al. (1980). After about 50 DAP the maize in 1996 the TDR measurements were carried out automatically. Each TDR probe was interfaced with cabling and multiplexers to the Tektronix Cable Tester, which was connected to a computer. Data from continuous automatic readings of each TDR probe were stored in the computer and transformed to soil water content by software. Multiplexers and software from Dynamax (Houston, TX, USA) were used. Values observed at 12:00 every three to four days were included in the data analysis.

Ceramic suction cups for sampling of the soil solution were installed through access holes in the wall of all lysimeters at soil depths of $0.15,0.30,0.60$ and $0.90 \mathrm{~m}$ after sowing the maize. At depths of 0.15 and $0.30 \mathrm{~m}$ two ceramic suction cups were installed per lysimeter, one in the maize row and one $0.3 \mathrm{~m}$ away from the row, the latter being located within the live cover crop strip in the LM plots.

The volume of leachate flowing out of the lysimeters was either sampled in 251 barrels and measured once a week (1994) or was recorded automatically with a gauge connected to a data logger and summed to give daily values (1995 and 1996). In both cases (soil solution and leachate) aliquots were separated for chemical analysis.

The soil solution was sampled at weekly intervals using laboratory syringes whenever the soil water potential was high enough $\left(\Psi_{\text {soil }}>-70 \mathrm{kPa}\right)$. The start of the sampling of the soil solution was delayed until 64 DAP in 1994. Both the leachate and 
the samples of the soil solution were analyzed for nitrate and ammonium concentrations using a colorimetric method (Evolution II Autoanalyser, Alliance Instruments, Nanterre, France). The sampling of the leachate and the soil solution was usually started at the sowing time of the maize crop and continued until the maize harvest, until the next spring or until the start of winter in the 1994, 1995 and 1996 experiments, respectively. The leachate volume and nitrate $\left(\left[\mathrm{NO}_{3}^{-}\right]-\mathrm{L}\right)$ and ammonium concentration $\left(\left[\mathrm{NH}_{4}^{+}\right]-\mathrm{L}\right)$ in the leachate were used to calculate the loss of $\mathrm{N}$ through leaching. The mean daily air temperature $\left({ }^{\circ} \mathrm{C}\right)$, daily total solar radiation $\left(\mathrm{kJ} \mathrm{m}^{-2}\right)$ and precipitation $(\mathrm{mm})$ were obtained from a nearby automatic meteorological weather station. Based on these data, the potential evapotranspiration (ETP) was calculated using the Jensen-Haise method (Burman and Pochop, 1994).

\section{Data analysis}

The experimental design in each experimental season was a completely randomized block with four replications and two treatments. The analysis of variance of all the data sets, except for nitrate $\left(\left[\mathrm{NO}_{3}^{-}\right]-\mathrm{SS}\right)$ and ammonium concentrations in the soil solution $\left(\left[\mathrm{NH}_{4}^{+}\right]-\mathrm{SS}\right)$, was performed with SAS ${ }^{\circledR}$, Proc Mixed (Littell et al., 1996). In the model specification the treatments and the replications were defined as fixed and random effects, respectively. For parameters repeatedly measured over time, one statistical analysis was calculated for each sampling date. The treatment means were classified according to results of pair-wise $\mathrm{t}$-tests whenever the F-test of the model was significant for the tested effect. The differences referred to as statistically significant in the results are so at a probability of $95 \%$, when not stated otherwise.

The $\left[\mathrm{NO}_{3}^{-}\right]-\mathrm{SS}$ and $\left[\mathrm{NH}_{4}^{+}\right]-\mathrm{SS}$ could not be analyzed with standard ANOVA procedures. These data sets were characterized by many missing values, especially during dry periods when it was impossible to extract soil solution with all the suction cups. In addition to the missing values, the examination of the distribution of the available $\left[\mathrm{NO}_{3}^{-}\right]-\mathrm{SS}$ and $\left[\mathrm{NH}_{4}^{+}\right]-$ $\mathrm{SS}$ values suggested that these were neither normally nor log-normally distributed. Graphical examination of the distributions indicated a strong skewness towards low values. For this reason it was decided to analyze these data sets with the non-parametric Wilcoxon rank sum test (Gibbons and Chakraborti,
1992) using the implementation available in the RPackage (Venables and Ripley, 2002). The Wilcoxon rank sum test provided treatment medians and pairwise treatment comparisons. To form the data sets for the Wilcoxon rank sum test, the available values of all replications of one treatment were pooled for the positions of the suction cups and/or the sampling dates. In 1994 the available $\left[\mathrm{NO}_{3}^{-}\right]-\mathrm{SS}$ and $\left[\mathrm{NH}_{4}^{+}\right]-\mathrm{SS}$ data sets were very small, and the values of the entire season and all the positions of the suction cups were pooled. In 1995 and $1996\left[\mathrm{NO}_{3}^{-}\right]-\mathrm{SS}$ and $\left[\mathrm{NH}_{4}^{+}\right]-\mathrm{SS}$ values were pooled in two different ways: (a) for each sampling date values of all positions of the suctions cups were pooled; (b) for each position of the suction cups values for early-, mid- and late-season sampling dates were pooled. Analyses were performed only for those subsets with at least 12 values for each treatment considered in the comparison.

\section{Results}

\section{Precipitation and evapotranspiration}

Figure 1 gives information about the water supply (precipitation plus irrigation) and water availability (the difference between cumulative precipitation and cumulative potential evapotranspiration) during the three crop seasons. The volumes of water provided by irrigation were 148, 20 and $0 \mathrm{~mm}$ in 1994, 1995 and 1996, respectively. The times and amounts of precipitation in 1994 and 1995 (Figure 1A) were similar and differed by only $5 \%$ at the end of the season. In both years the precipitation was as follows: (i) intense rainfall early in the season (until 35 DAP), amounting to almost $50 \%$ of the precipitation throughout the season, (ii) an intermediate period with moderate rainfalls between 35 and 90 DAP, (iii) intense rainfall towards the end of the season. In 1996 the distribution and intensity of the precipitation differed from 1994 and 1995: about 35\% lower with little rainfall early (period I) and late (period III) in the season. In 1996 the most precipitation ( $65 \%$ of the total precipitation) fell at the same time as the dry periods in 1994 and 1995.

A rough idea of water availability is given by the difference between the water supply (cumulative precipitation plus irrigation) and the demand (cumulative potential evapotranspiration, ETP) (Figure 1B). Precipitation generally exceeded the demand in all three seasons. The crop seasons in 1994 and 1995 were similar, with a huge excess of water early in the season, 


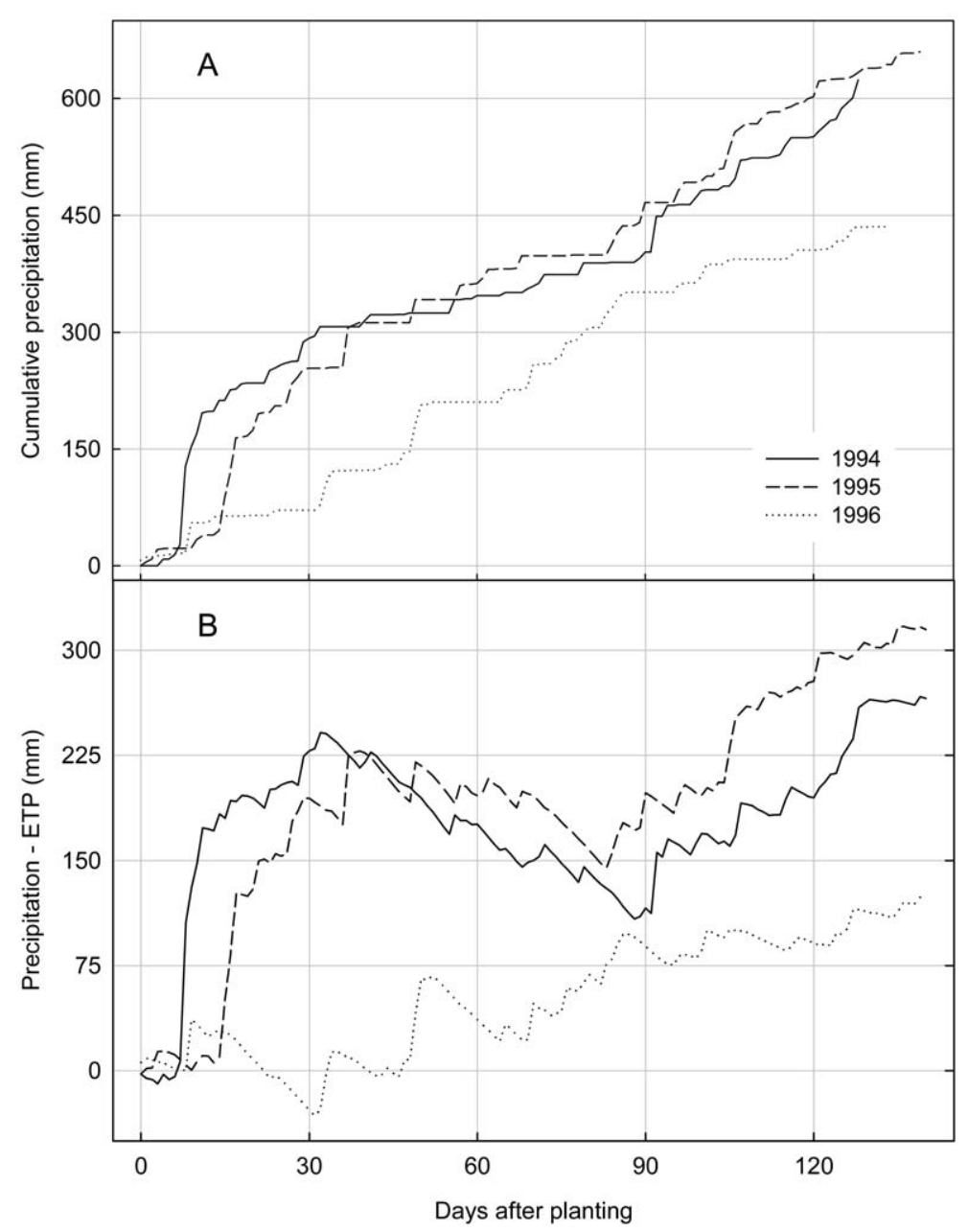

Figure 1. Characteristics of supply (precipitation, A) and availability (difference between potential evapotranspiration, ETP, and precipitation, B) of water. Precipitation includes irrigation.

which increased until 30 to 40 days after planting. The excess of water decreased steadily until about anthesis and then increased again. In 1996 the excess of water was smaller compared to the other two years over the entire crop season: a short period of water deficit occurred around 30 DAP and only a small increase in the excess of water was observed after anthesis. The marked difference between water availability in 1996 and the other two years was mainly a consequence of seasonal rainfall, which was $664 \mathrm{~mm}$ in 1994, 662 in 1995 and 462 in 1996, while the respective ETP values were 387,364 and $339 \mathrm{~mm}$.

\section{Leaching}

Patterns of leaching during the maize crop season (Figure 2) were similar for all year $\mathrm{x}$ treatment com- binations and the amounts differed by only 5\%. The volume of leachate during the entire 1995 season was much higher compared to the other two years in both treatments. (The leachate volume in 1994 was underestimated. Samples were lost during an intense rainfall period $-189 \mathrm{~mm}$ within seven days - starting five days after the sowing of maize.)

Despite the strong seasonal variations in leaching, the differences between BS and LM are very clear: the volume of leachate in the three experimental years was almost always greater in the BS plots. At single sampling dates the BS treatment exceeded the LM by as much as $35 \mathrm{~mm}$, but the differences were not always significant.

The temporal patterns of $\left[\mathrm{NO}_{3}^{-}\right]-\mathrm{L}$ during the maize crop season in the BS and LM plots are plotted for the three experimental years in Figure 3. The 


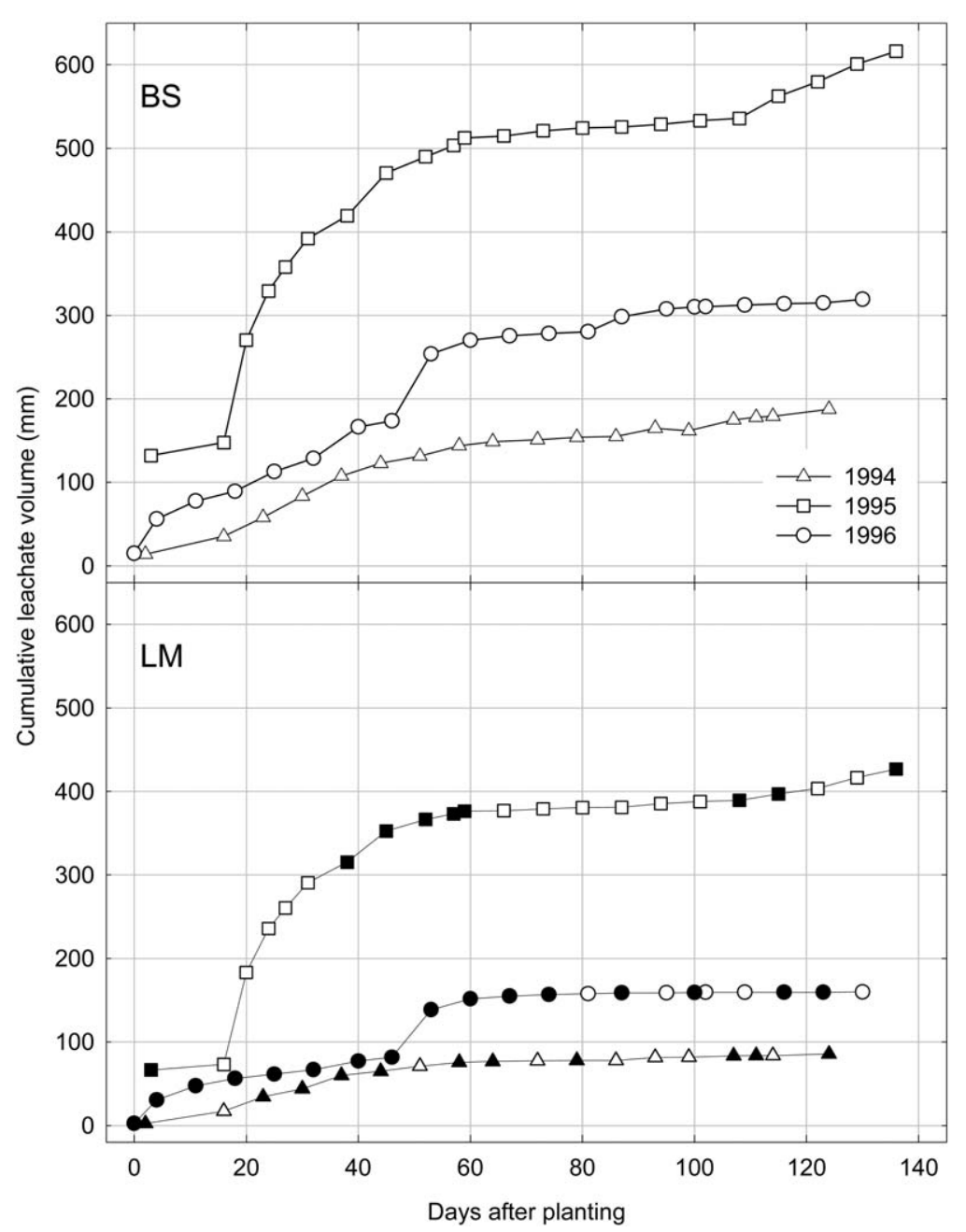

Figure 2. Cumulative leachate volume during the maize season in bare soil (BS) and living mulch (LM) in the three experimental years. Filled symbols represent sampling dates, on which the measured leachate volume was significantly different in the BS and LM plots $(P<0.05)$ according to pair-wise $t$-tests.

$\left[\mathrm{NO}_{3}^{-}\right]-\mathrm{L}$ in the BS plots followed a similar pattern in 1994 and 1995: (i) early season $\left[\mathrm{NO}_{3}^{-}\right]-\mathrm{L}$ of 10 and $15 \mathrm{mg} \mathrm{L}^{-1}$ increased to a maximum of approximately 40 (1994) and $23 \mathrm{mg} \mathrm{L}^{-1}$ (1995) between 35 and $45 \mathrm{DAP}$, (ii) $\left[\mathrm{NO}_{3}^{-}\right]-\mathrm{L}$ decreased to values below $10 \mathrm{mg} \mathrm{L}^{-1}$ before anthesis (1995) or after anthesis (1994) and (iii) $\left[\mathrm{NO}_{3}^{-}\right]-\mathrm{L}$ remained more or less below $10 \mathrm{mg} \mathrm{L}^{-1}$ until harvest, with a slight increase towards the end of the season. This pattern of $\left[\mathrm{NO}_{3}^{-}\right]-$ L was also observed in 1996, but the values were much higher, with the exception of early in the season. The maximum $\left[\mathrm{NO}_{3}^{-}\right]-\mathrm{L}$ exceeded $70 \mathrm{mg} \mathrm{L}^{-1}$. Although there was a decrease after anthesis, $\left[\mathrm{NO}_{3}^{-}\right]-\mathrm{L}$ was above $30 \mathrm{mg} \mathrm{L}^{-1}$ until the maize harvest.
The $\left[\mathrm{NO}_{3}^{-}\right]-\mathrm{L}$ was much lower in the $\mathrm{LM}$ than in the BS plots during the entire maize crop season in the three experimental years (usually below $1.0 \mathrm{mg} \mathrm{L}^{-1}$ ). Early in the season (until $60 \mathrm{DAP}$ ) the $\left[\mathrm{NO}_{3}^{-}\right]-\mathrm{L}$ in the LM plots was almost always significantly lower than in the BS plots. Later in the season, when the $\left[\mathrm{NO}_{3}^{-}\right]-\mathrm{L}$ had decreased to below the maximum seasonal value, the differences between the two cropping systems were not always significant. The highest $\left[\mathrm{NO}_{3}^{-}\right]-\mathrm{L}$ in the $\mathrm{LM}$ plots were found in 1996, sometimes exceeding $10 \mathrm{mg} \mathrm{L}^{-1}$.

The $\left[\mathrm{NH}_{4}^{+}\right]-\mathrm{L}$ (data not shown) were generally low, ranging from 0.02 to $0.14 \mathrm{mg} \mathrm{L}^{-1}$ in the BS plots in the three experimental seasons. In the whole experi- 


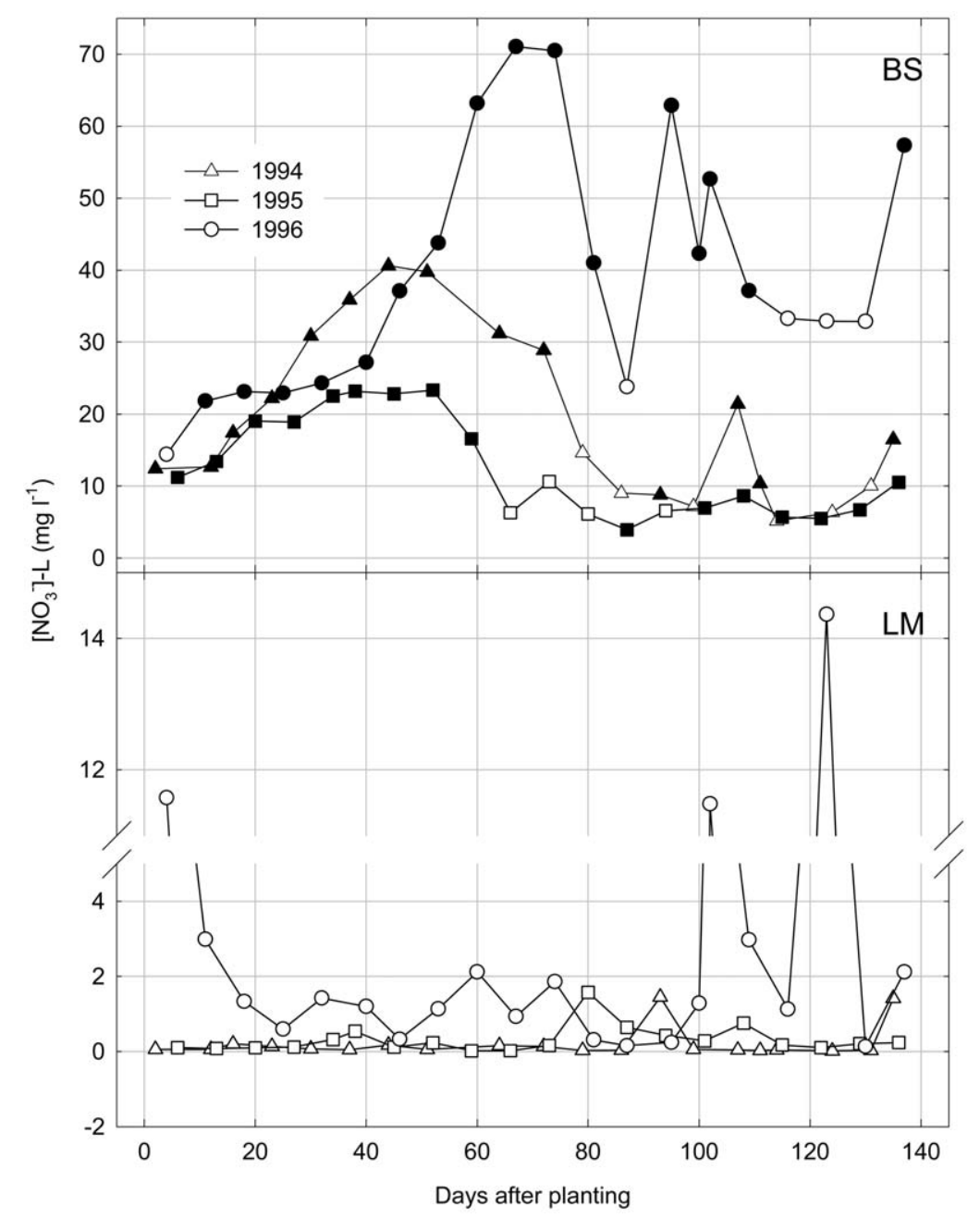

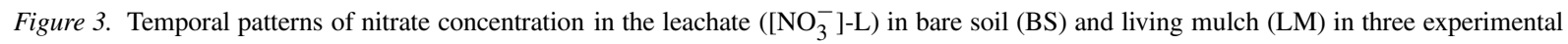
years. Filled symbols represent sampling dates, on which the measured $\left[\mathrm{NO}_{3}^{-}\right]-\mathrm{L}$ was significantly different for the BS and the $\mathrm{LM}$ treatments $(P<0.05)$ according to pair-wise $t$-tests.

ment the $\left[\mathrm{NH}_{4}^{+}\right]-\mathrm{L}$ was significantly higher in the BS plots than in the LM plots on one sampling date only.

The cumulative losses of $\mathrm{N}$ observed in the BS and LM plots in the three experimental years are plotted in Figure 4. Most of the N lost through leaching was observed during the first 50 days of the season, reaching 947 (1994), 1524 (1995) and $1660 \mathrm{mg} \mathrm{m}^{-2}$ (1996). These values correspond to 75,87 and $62 \%$ of the total $\mathrm{N}$ lost through leaching in the entire maize crop season. Almost no nitrogen was lost through leaching in the LM plots. The largest amount $\left(129 \mathrm{mg} \mathrm{m}^{-2}\right)$, in 1996, was less than $5 \%$ of the amount of $\mathrm{N}$ lost in the BS treatment. The seasonal values in the other years were only 0.6 (1994) and 1.6\% (1995) of those in the BS plots. As in the BS treatment, most of the $\mathrm{N}$ losses through leaching in the LM plots were observed until 50 DAP; 68,81 and $93 \%$ of the seasonal $\mathrm{N}$ losses in 1994, 1995 and 1996, respectively.

\section{Nitrogen in soil solution}

In 1994 the small data sets allowed only for a rough analysis of $\left[\mathrm{NO}_{3}^{-}\right]$-SS. The data were pooled over all sampling dates starting at $64 \mathrm{DAP}$ and for all positions of suction cups. A median $\left[\mathrm{NO}_{3}^{-}\right]-\mathrm{SS}$ of 1.87 was calculated for the BS plots and $0.16 \mathrm{mg} \mathrm{L}^{-1}$ for the LM plots. The difference between the cropping systems was significant at a probability level of 0.001 .

The effect of the BS and LM treatments on the $\left[\mathrm{NO}_{3}^{-}\right]-\mathrm{SS}$ in 1995 and 1996 are shown in Figure 5. 


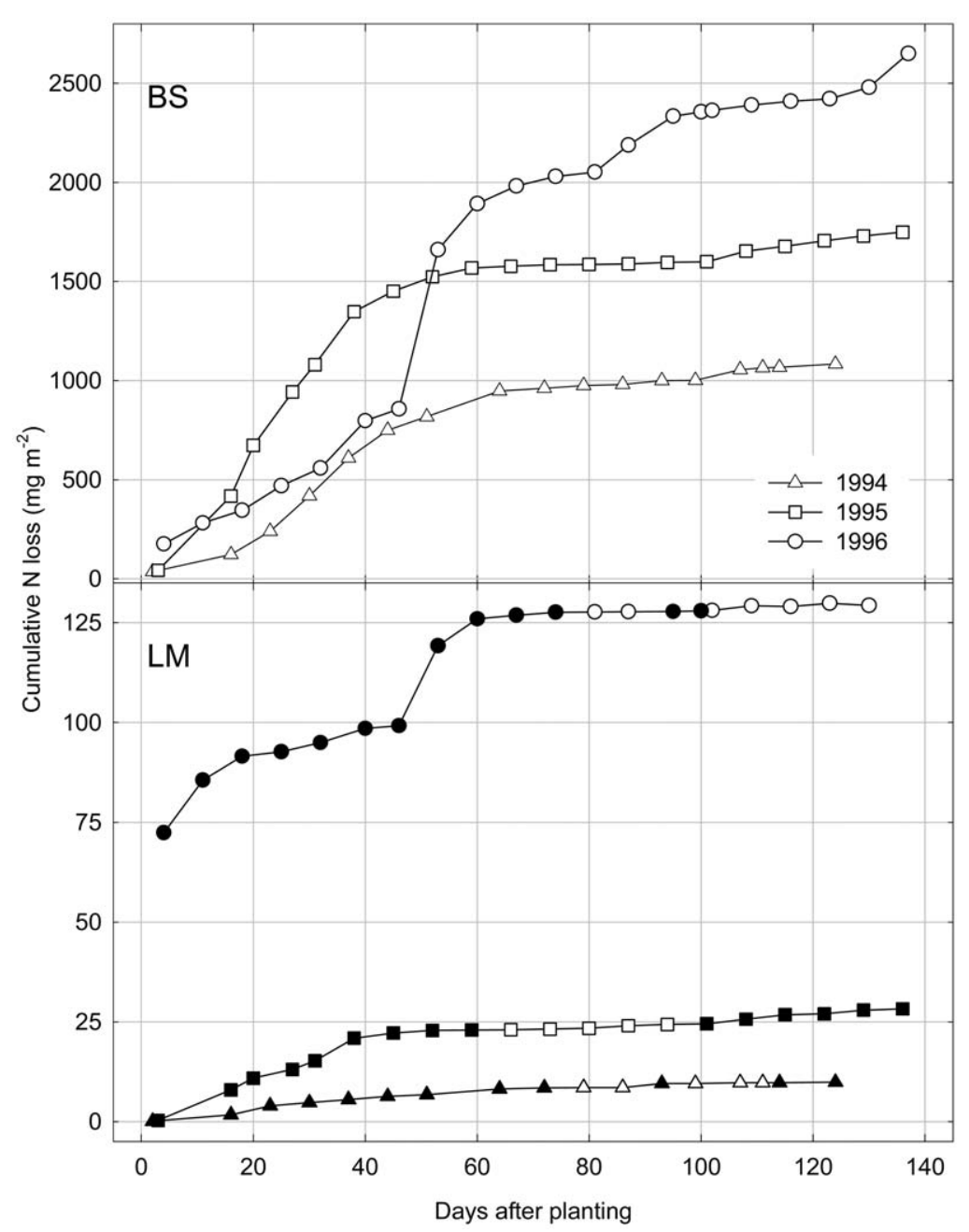

Figure 4. Cumulative loss of $\mathrm{N}$ in bare soil (BS) and living mulch (LM) in three experimental years. Filled symbols represent sampling dates, on which the calculated loss of $\mathrm{N}$ was significantly different for the BS and LM plots $(P<0.05)$ according to pair-wise $t$-tests.

With a single exception (32 DAP, 1995), $\left[\mathrm{NO}_{3}^{-}\right]-\mathrm{SS}$ were lower in the LM than in the BS plots in both years, and the differences were almost always significant. The $\left[\mathrm{NO}_{3}^{-}\right]-\mathrm{SS}$ was high to very high in the BS plots from the start of the season until 59 DAP (1995) and 87 DAP (1996). At later sampling dates the $\left[\mathrm{NO}_{3}^{-}\right]-\mathrm{SS}$ in the BS plots were markedly lower. The $\left[\mathrm{NO}_{3}^{-}\right]-\mathrm{SS}$ in the LM plots was also higher on early sampling dates than on later sampling dates. The decreases in the $\left[\mathrm{NO}_{3}^{-}\right]-\mathrm{SS}$ in the LM plots towards the end of the cropping seasons were much bigger (by a factor of 10 to 75) compared to the BS plots. The very low $\left[\mathrm{NO}_{3}^{-}\right]-\mathrm{SS}$ in the $\mathrm{LM}$ plots was also found earlier, at 52 (1995) and 74 DAP (1996), than in the BS plots (101 DAP in 1995 and 95 DAP in 1996).
The effects of the BS and LM treatments on the $\left[\mathrm{NO}_{3}^{-}\right]$-SS depending on soil location in early-, midand late season are listed in Table 2. As for the seasonal patterns, the $\left[\mathrm{NO}_{3}^{-}\right]-\mathrm{SS}$ was almost always significantly higher in the BS than in the LM plots; the differences between the cropping systems often varied by a factor of 10 and more. The smallest differences between the two cropping systems were found early in the season in the top soil layers $(0.15$ and $0.30 \mathrm{~cm})$ of the maize row in both years. Early in the season the $\left[\mathrm{NO}_{3}^{-}\right]-\mathrm{SS}$ decreased with soil depth in the maize row in the LM plots in both years. This pattern was also observed in the BS plots in 1996 but not in 1995 when the $\left[\mathrm{NO}_{3}^{-}\right]-\mathrm{SS}$ varied little along the soil profile. Irrespective of the treatment and year, the top soil $\left[\mathrm{NO}_{3}^{-}\right]-\mathrm{SS}$ early in the season was higher in the 


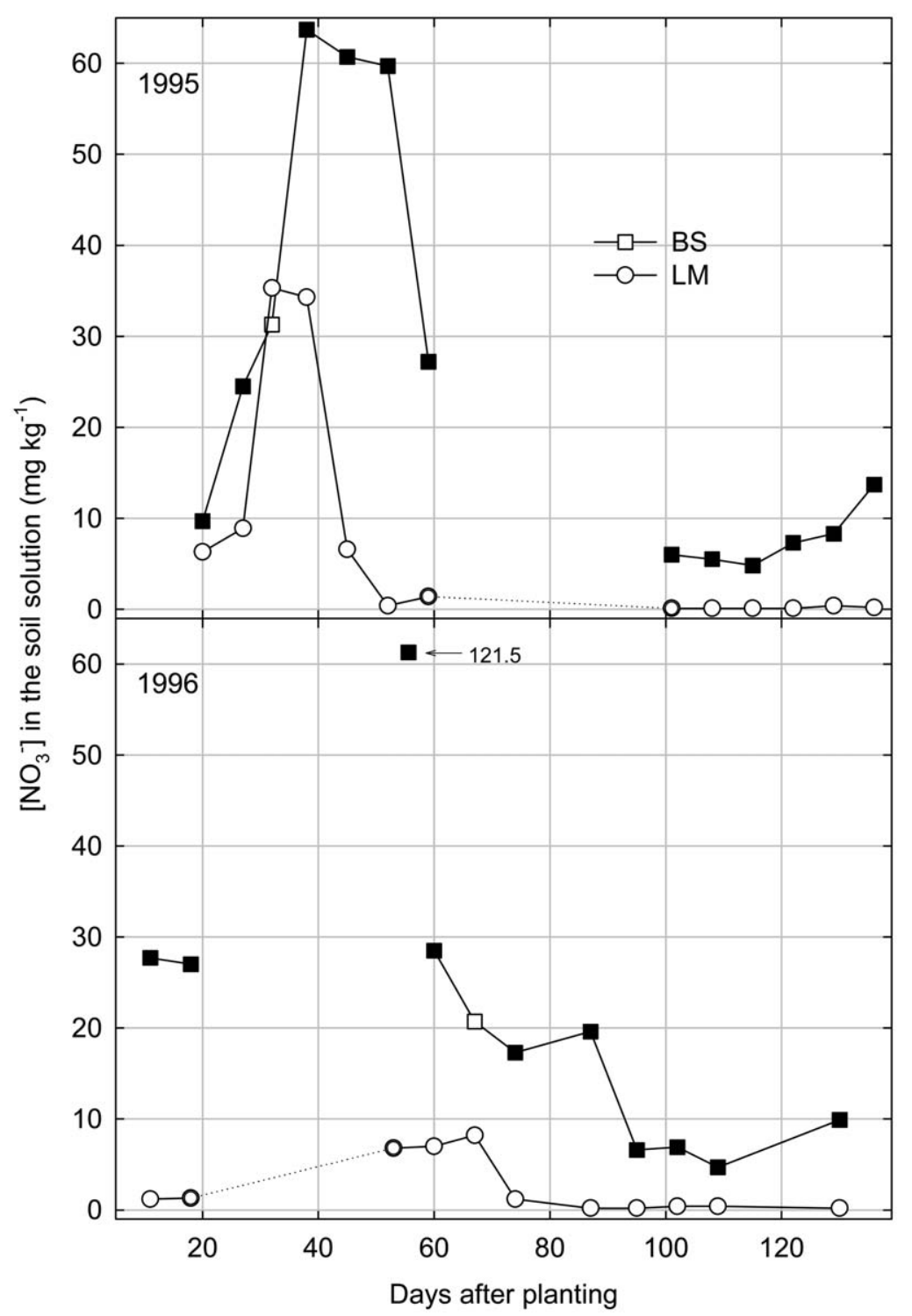

Figure 5. Median nitrate concentrations in the soil solution ([NO $\left.\left.{ }_{3}^{-}\right]-\mathrm{SS}\right)$ in bare soil (BS) and living mulch (LM) in 1995 and 1996. Filled symbols represent sampling dates, on which the $\left[\mathrm{NO}_{3}^{-}\right]$-SS was significantly different for the $\mathrm{BS}$ and $\mathrm{LM}$ plots $(P<0.05)$ according to the non-parametric Wilcoxon rank sum test. Dotted lines represent periods, for which median $\left[\mathrm{NO}_{3}^{-}\right]-\mathrm{SS}$ values could not be calculated because of missing samples. Each value represents the median $\left[\mathrm{NO}_{3}^{-}\right]-\mathrm{SS}$ of all suction cups available for the target treatment on the sampling date.

maize row compared to values observed $0.30 \mathrm{~m}$ from the row. Information about mid-season $\left[\mathrm{NO}_{3}^{-}\right]-\mathrm{SS}$ is available only for 1996, in which, compared to early in the season, it decreased strongly in the top soil $(0.15$ and $0.30 \mathrm{~m}$, within and between the maize rows) and increased in subsoil layers $(0.60$ and $0.90 \mathrm{~m})$. This effect was more evident in the BS treatment; the values for the LM plots were already low early in the season. There were only small changes in the $\left[\mathrm{NO}_{3}^{-}\right]-$ $\mathrm{SS}$ in the top soil (15 and 30, within and between the maize rows) between the mid- and late season in both treatments. The high mid-season $\left[\mathrm{NO}_{3}^{-}\right]-\mathrm{SS}$ at depths of 0.60 and $0.90 \mathrm{~m}$ decreased late in the season in both cropping systems, although the values were higher than the corresponding values for the top soil, especially in the BS plots.

The $\left[\mathrm{NH}_{4}^{+}\right]$-SS was usually very low, ranging from 0 (both cropping systems) to 0.26 and $0.55 \mathrm{mg} \mathrm{L}^{-1}$ in the BS and LM plots, respectively. The differences between the BS and LM plots were seldom significant. 
Table 2. Median nitrate concentrations in the soil solution as observed under maize grown in a bare soil (BS) and a living mulch (LM) in 1995 and 1996 at different locations in the soil profile

\begin{tabular}{|c|c|c|c|c|c|c|c|c|}
\hline \multirow{4}{*}{$\begin{array}{l}\text { Period } \\
\text { Early-season }\end{array}$} & \multirow{4}{*}{$\begin{array}{l}\text { Distance from } \\
\text { maize row } \\
\mathrm{m}\end{array}$} & \multirow{4}{*}{$\begin{array}{l}\text { Soil depth } \\
\mathrm{m} \\
0.15\end{array}$} & \multirow{3}{*}{$\begin{array}{l}1995 \\
\text { BS }\end{array}$} & \multirow{3}{*}{ LM } & \multirow{3}{*}{$\mathrm{mg} \mathrm{L}^{-1}$} & \multirow{3}{*}{$\begin{array}{l}1996 \\
\text { BS }\end{array}$} & \multirow{3}{*}{ LM } & \\
\hline & & & & & & & & \\
\hline & & & & & & & & \\
\hline & & & 48.1 & 84.4 & & 216.1 & 158.5 & \\
\hline & & 0.30 & 69.5 & 39.6 & $\dagger$ & na & na & \\
\hline & & 0.60 & 63.9 & 16.8 & $* *$ & 77.0 & 4.7 & $* *$ \\
\hline & & 0.90 & 61.1 & 2.9 & $* * *$ & 41.4 & 3.1 & $* * *$ \\
\hline & 0.30 & 0.15 & 6.7 & 0.2 & $* * *$ & 22.3 & 0.8 & $* * *$ \\
\hline & & 0.30 & 12.2 & 0.3 & $* * *$ & 32.7 & 0.8 & $* *$ \\
\hline Mid-season & 0.00 & 0.15 & na & na & & 2.3 & 0.3 & $* *$ \\
\hline & & 0.30 & na & na & & 5.4 & 1.9 & $\dagger$ \\
\hline & & 0.60 & na & na & & 73.4 & 20.4 & $* *$ \\
\hline & & 0.90 & na & na & & 108.6 & 7.4 & $* * *$ \\
\hline & 0.30 & 0.15 & 20.3 & 0.2 & $* * *$ & 7.8 & 0.3 & $* * *$ \\
\hline & & 0.30 & na & na & & 7.6 & 0.2 & $* * *$ \\
\hline Late-season & 0.00 & 0.15 & 5.9 & 0.6 & $* * *$ & 2.7 & 0.3 & $* * *$ \\
\hline & & 0.30 & 7.2 & 0.2 & $* * *$ & 5.8 & 0.5 & $* * *$ \\
\hline & & 0.60 & 9.2 & 0.2 & $* * *$ & 11.7 & 0.8 & $* * *$ \\
\hline & & 0.90 & 13.5 & 0.1 & $* * *$ & 31.1 & 1.2 & $* * *$ \\
\hline & 0.30 & 0.15 & 4.4 & 0.1 & $* * *$ & 4.3 & 0.2 & $* * *$ \\
\hline & & 0.30 & 9.6 & 0.2 & $* * *$ & 6.8 & 0.2 & $* * *$ \\
\hline
\end{tabular}

$\dagger, *, * *, * * *$ significant at the $0.10,0.05,0.01$ and 0.001 probability level, respectively.

Early season sampling dates between 20 and 52 (1995) and 11 and 53 DAP (1996).

Mid-season sampling dates between 59 and 94 (1995) and 60 and 95 DAP (1996).

Late season sampling dates between 101 and 136 (1995) and 102 and 141 DAP (1996).

na Median $\left[\mathrm{NO}_{3}^{-}\right]$-SS values could not be calculated because too many samples were missing.

\section{Soil water content}

Figure 6 shows the plots of volumetric soil water content in the BS and LM plots for the horizontally installed TDR-probes at depths of $0.3,0.6$ and $0.9 \mathrm{~m}$ for the three experimental years. A common pattern of soil water content was observed for both treatments, all years and all depths. Early in the season, the soil water content was high and decreased to minimum values around maize anthesis or later. After the minimum was reached, the soil water contents recovered to varying extents towards the end of the season. In 1994 a decrease in the soil water content towards maize anthesis was not found for all soil depth $\times$ cropping system combinations. This was probably due to the late measurement start, because the general pattern was found in the BS plots at depths of 0.6 and $0.9 \mathrm{~m}$ and in the LM plots at $0.9 \mathrm{~m}$. The strongest deviation from the general pattern of soil water content was found in 1996 when the soil water content increased only slightly or not at all towards the end of the season in both cropping systems.
The soil water content at depths of $0.3,0.6$ and $0.9 \mathrm{~m}$ was almost always smaller in the LM than in the BS plots; these differences were often significant. While significant differences between the soil water content in the two cropping systems were found during the season at soil depths of 0.3 and $0.6 \mathrm{~cm}$, such differences were not found until about maize anthesis at a depth of $0.9 \mathrm{~cm}$ in 1994 and 1996.

Figure 7 shows the volumetric soil water content measured with the vertically installed TDR probes between 0.0 and $0.3 \mathrm{~m}$ in the maize row and $0.3 \mathrm{~m}$ away from the maize row. Differences in the soil water content in the top soil between the two cropping systems were seldom significant and were not as large as the differences in deeper soil layers. Sometimes and especially early in the season in 1995, the soil water contents measured in the top soil were greater in the LM than in the BS plots. 


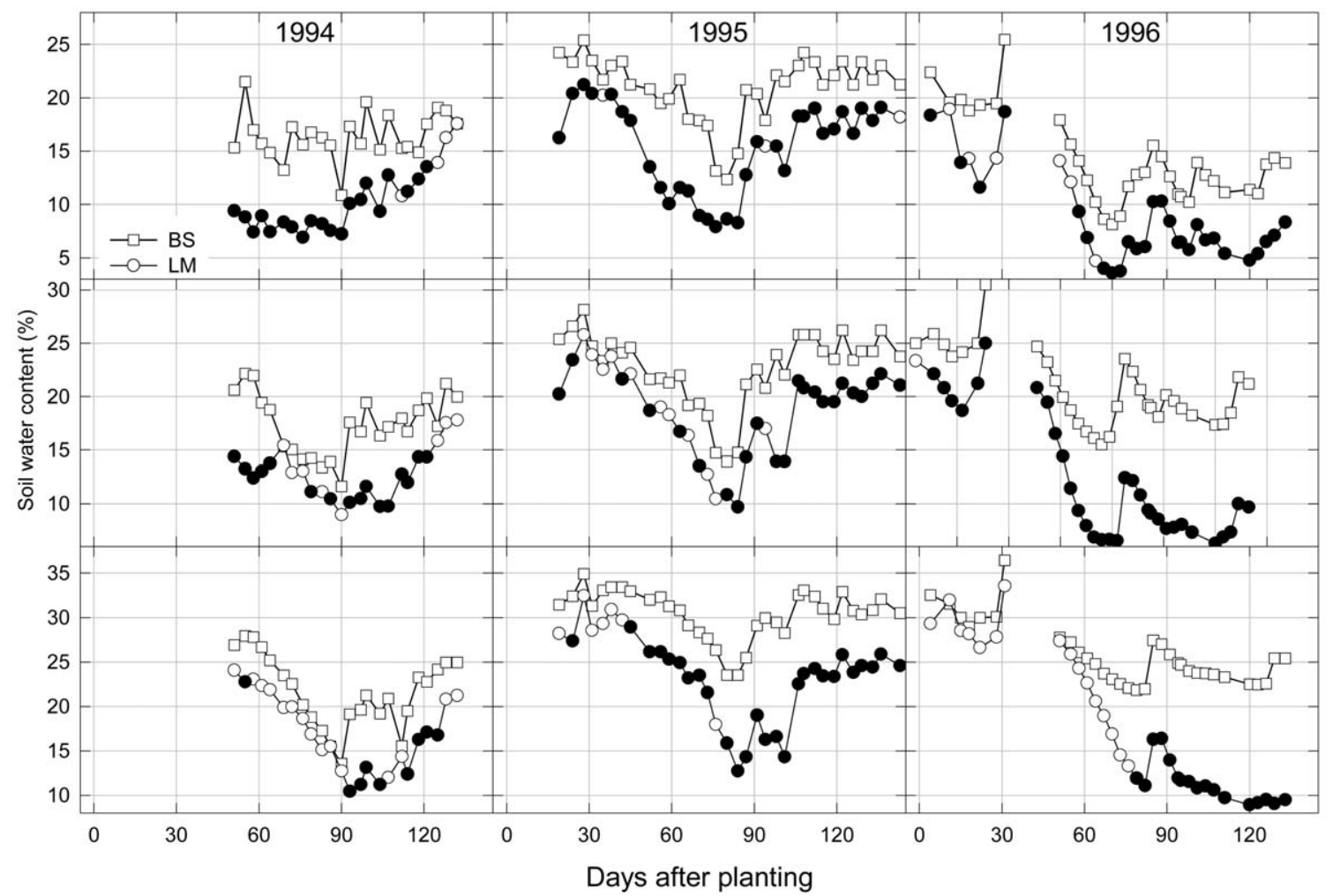

Figure 6. Variation in volumetric soil water content in bare soil (BS) and living mulch (LM) as measured with horizontally installed TDR probes at depths of $0.3,0.6$ and $0.9 \mathrm{~m}$ in the soil in the three experimental years. Filled symbols represent sampling dates, on which soil water content was significantly different for the BS and LM plots $(P<0.05)$ according to pair-wise $t$-tests.

\section{Nitrogen content of maize plants at harvest}

The effects of the BS and LM treatments on $\mathrm{N}$ related yield parameters are displayed in Table 3 . The nitrogen yield from grains and stover were always significantly lower in the LM than in the BS plots. The effect of the cropping system on the stover $\mathrm{N}$ content was stronger than on the grain $\mathrm{N}$ content. On a relative basis, the $\mathrm{N}$ harvest index was the $\mathrm{N}$ parameter least affected by the two cropping systems and was significantly higher in the LM plots only in 1996. The nitrogen concentrations were often but not always higher in the BS than in the LM plots.

\section{The $N$ balance of the cropping systems}

Table 4 lists the measured components of the $\mathrm{N}$ balances in the BS and LM plots during the three experimental years. The $\mathrm{N}$ export exceeded the inputs in both cropping systems in the three experimental years, resulting in an $\mathrm{N}$ deficit which varied from 7.2 to $32.7 \mathrm{~g} \mathrm{~m}^{-2}$ (maize silage yield) and from 1.7 to $17.9 \mathrm{~g} \mathrm{~m}^{-2}$ (maize grain yields). In quantitative terms the most relevant factor in the N-balance was the export of $\mathrm{N}$ in the shoot biomass of the maize plants (BS plots) and in the maize and grass plants (LM plots). In 1994 and 1995 the export of $\mathrm{N}$ in the harvested plant shoots was 10 and $15 \%$ lower in the LM compared to the BS plots, respectively, while in $199647 \%$ more $\mathrm{N}$ was exported from the LM than from the BS plots. Fertilizer $\mathrm{N}$ input represented only a small portion of the $\mathrm{N}$ exported in the plant shoots: 42 and $46 \%$ in the BS and LM plots in 1994, 26 and 31\% in 1995 and 71 and $48 \%$ in 1996. Leaching losses were irrelevant for the $\mathrm{N}$ balance in the LM treatment, while it was responsible for $6 \%$ of the $\mathrm{N}$ deficit in 1994 and 1995 in the BS treatment. Only in 1996 were the losses of N through leaching of the BS plots proportionally high, contributing $37.5 \%$ to the overall $\mathrm{N}$ deficit.

\section{Discussion}

The data presented in this publication show that a living mulch of Italian ryegrass strongly reduces the 


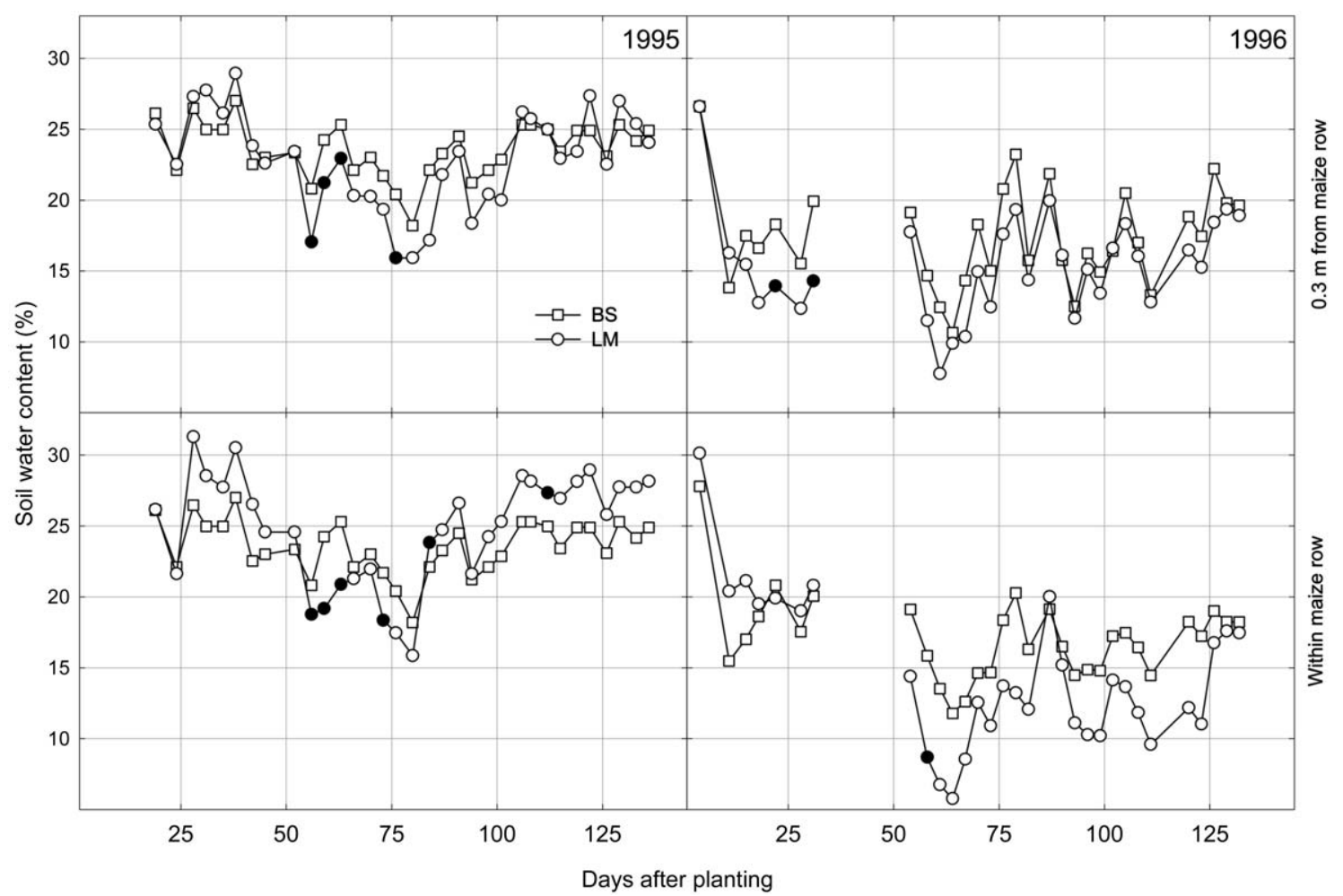

Figure 7. Variation in volumetric soil water content in bare soil (BS) and living mulch (LM) as measured with vertically installed TDR probes at depths from 0.0 to $0.3 \mathrm{~m}$ in the soil in the maize row and $0.3 \mathrm{~m}$ away from the row in 1995 and 1996 . Filled symbols represent sampling dates, on which soil water content was significantly different for the BS and LM plots $(P<0.05)$ according to pair-wise $t$-tests.

availability of nitrogen in the whole soil profile (Figure 5, Table 2) and of water at a soil depth of $0.3 \mathrm{~m}$ and below (Figure 6) compared to maize sown into a bare soil. These observations are the basis for the postulated environmental advantages of cropping maize in living mulch systems in terms of contamination of the ground water by nitrate (Feil et al., 1997): the leachate volume (Figure 2) and the nitrate concentrations in the leachate (Figure 3 ) and thus the losses of nitrogen through leaching (Figure 4) decrease, in contrast to the sowing of maize into a bare soil. However, the reduced availability of nitrogen and water in the living mulch system is also responsible for reducing the growth and yield of maize, as shown for this data set (Liedgens et al., 2003) and reported elsewhere for nitrogen (Box et al., 1980; De Haan et al., 1994; Feil et al., 1997; Garibay et al., 1997; Martin et al., 1999; Robertson et al., 1976; Zemenchik et al., 2000; Wilkinson et al., 1987), water (Kumwenda et al., 1993; Wilkinson et al., 1987) or both (Carreker et al., 1972; Eberlein et al., 1992; Heyland and Werner, 1988; Kurtz et al., 1946, 1952).
The Italian ryegrass living mulch systematically reduces the availability of soil water at all depths starting at $0.3 \mathrm{~m}$ (Figure 6). This is true even in periods of very intense rainfall, as was the case early in 1995 (Figure 1), which was accompanied by intensive deep percolation of water (Figure 2). Such an excess of water was not enough to completely and consistently replenish the soil water content of the LM plots compared to the BS plots.

The dry soil during the second half of the crop season in 1996 in the LM treatment may help to explain why the growth of the leaf area of maize was not significantly affected by the cropping systems, while the grain yields were significantly lower in the LM treatment (Liedgens et al., 2003).

It is interesting that these very evident effects of the living mulch on soil water contents from 0.3 to $0.9 \mathrm{~m}$ (Figure 6) were not found from 0.0 to $0.3 \mathrm{~m}$ (Figure 7). The intensive uptake of water by the plants, supported by the high root densities in the LM and BS plots in these soil layers (Liedgens et al., 2003) as well as the immediate response to rainfall are the cause of fast changes in the soil water content in the 0.0 to $0.3 \mathrm{~m}$ ho- 
Table 3. Nitrogen related traits in maize shoots grown in a bare soil (BS) and a living mulch (LM) at harvest in three experimental years

\begin{tabular}{|c|c|c|c|c|c|c|c|c|c|c|}
\hline & \multicolumn{2}{|c|}{ Grain N yield } & \multicolumn{2}{|c|}{ Stover N yield } & \multicolumn{2}{|c|}{$\mathrm{N}$ harvest index } & \multicolumn{2}{|c|}{ Grain N conc. } & \multicolumn{2}{|c|}{ Stover N conc. } \\
\hline & $\mathrm{BS}$ & $\mathrm{LM}$ & $\begin{array}{l}\text { BS } \\
\qquad(\mathrm{g} \mathrm{n}\end{array}$ & $\begin{array}{l}\text { LM } \\
-2)\end{array}$ & $\mathrm{BS}$ & $\mathrm{LM}$ & $\mathrm{BS}$ & $\mathrm{LM}$ & BS & LM \\
\hline 1994 & $14.4 \mathrm{a}$ & $2.9 \mathrm{~b}$ & $12.0 \mathrm{a}$ & $2.1 \mathrm{~b}$ & 54.6 & 57.4 & 1.80 & 1.29 & 1.21 & 0.96 \\
\hline 1995 & $22.7 \mathrm{a}$ & $13.9 \mathrm{~b}$ & $19.0 \mathrm{a}$ & $6.4 \mathrm{~b}$ & 54.0 & 67.0 & 2.28 & 2.46 & $1.06 \mathrm{a}$ & $0.61 \mathrm{~b}$ \\
\hline 1996 & $10.0 \mathrm{a}$ & $6.4 \mathrm{~b}$ & $5.5 \mathrm{a}$ & $2.0 \mathrm{~b}$ & $64.8 \mathrm{~b}$ & $75.9 \mathrm{a}$ & $1.53 \mathrm{a}$ & $1.13 \mathrm{~b}$ & $1.20 \mathrm{a}$ & $0.62 \mathrm{~b}$ \\
\hline
\end{tabular}

Means followed by different letters are significantly different $(P<0.05)$, according to pair-wise $t$-test comparisons.

Table 4. Nitrogen balance for maize grown in a bare soil (BS) and a living mulch (LM) at harvest in three experimental years

\begin{tabular}{|c|c|c|c|c|c|c|}
\hline & \multicolumn{2}{|l|}{1994} & \multicolumn{2}{|l|}{1995} & \multicolumn{2}{|l|}{1996} \\
\hline & \multicolumn{6}{|c|}{$\mathrm{g} \mathrm{m}^{-2}$} \\
\hline $\mathrm{N}$ grain & -14.4 & -5.9 & -22.7 & -13.9 & -10.0 & -6.4 \\
\hline $\mathrm{N}$ stover & -12.0 & -2.1 & -19.0 & -6.4 & -5.5 & -2.0 \\
\hline $\mathrm{N}$ grass shoots ${ }^{\mathrm{a}}$ & - & -15.9 & - & -15.0 & - & -14.5 \\
\hline $\mathrm{N}$ fertilizer & +11.0 & +11.0 & +11.0 & +11.0 & +11.0 & +11.0 \\
\hline $\mathrm{N}$ leaching loss & -1.0 & 0.0 & -2.0 & 0.0 & -2.7 & -0.1 \\
\hline $\mathrm{N}$ deficit silage ${ }^{\mathrm{b}}$ & -16.4 & -12.9 & -32.7 & -24.3 & -7.2 & -12.0 \\
\hline $\mathrm{N}$ deficit grain ${ }^{\mathrm{c}}$ & -4.4 & -10.8 & -13.7 & -17.9 & -1.7 & -10.0 \\
\hline $\begin{array}{l}\text { Sum of grass har } \\
\text { Maize grains and } \\
\text { Maize grains rem } \\
\text { deficits include }\end{array}$ & $\begin{array}{l}\text { s durin } \\
\text { ver rer } \\
\text { d from }\end{array}$ & $\begin{array}{l}\text { the maiz } \\
\text { ved from } \\
\text { le field }\end{array}$ & $\begin{array}{l}\text { crop seas } \\
\text { he field }\end{array}$ & & & \\
\hline
\end{tabular}

rizon and, consequently, it was not possible to identify differences between the cropping systems in this soil layer. Fast changes in the water content of the upper soil layer measured by TDR were also observed by Martin et al. (1999). However, it was in this soil layer that they observed the most pronounced differences in soil water content between the living mulch and the conventionally cropped maize treatments.

Kumwenda et al. (1993), measuring soil water content with TDR probes to a depth of $1.2 \mathrm{~m}$, observed a reduction in the soil water content during the crop season in a maize - Trifolium incarnatum living mulch between the 0.15 to $0.30 \mathrm{~m}$ but not at any other soil depth. These results show the importance of monitoring the soil water content in the whole soil profile in order to accurately characterize the water dynamics in different cropping systems.

Soil water is depleted by percolation, evaporation and uptake by the plants, from which it is transpired. The lower soil water content in the LM compared to the BS treatment must be due to the effect of the treat- ment on these three components. Deep percolation can not be the reason, because the cumulative loss of water through leaching was $50 \%$ or lower in the LM compared to the BS plots in the three crop seasons (Figure 2). Evaporation was not measured, but it is unlikely that it was higher in the LM than in the BS plots, as uncovered soil is more exposed and susceptible to evaporation (Tolk et al., 1999).

Hence, transpiration is the most likely cause of the lower soil water content in the LM than in the BS treatment. The maize leaf area is a good measure of the transpiratory demand of the plants (Al Kaisi et al., 1989). Since it was generally lower in the LM than in the BS plots, it can be assumed that transpiration by the maize plants was lower in the LM treatment. Thus, the Italian ryegrass plants must have lead to higher transpiration in the LM compared to the BS treatment and are the reason for the decreased soil water contents observed. Liedgens et al. (2003) found much higher root densities for almost all the sampling dates, soil depths and positions relative to the maize row in 
the LM compared to the BS plots. The increased root densities in the LM treatment are in agreement with the more intense soil water depletion described above and should be able to sustain an increased demand of water for transpiration.

In agreement with our results there are many reports in the literature indicating that the availability of soil water limits the main crop in living mulch systems (Adams et al., 1970; Eberlein et al., 1992; Heyland and Werner, 1988; Kumwenda et al., 1993; Nicholson and Wien, 1983). However, there are also studies showing different characteristics of the soil water content from those described here. Martin et al. (1999) found higher soil water contents $(0.0$ to $0.5 \mathrm{~m}$ soil depth) in a living mulch (partially controlled grass sward with a patchy infestation of white clover) compared to conventional maize cropping and attributed this difference to less evaporation and a greater infiltration of water in the living mulch system. Carreker et al. (1972) found water consumption to be faster before canopy closure and slower after in a irrigated living mulch compared to a dead mulch of Festuca elatior var. arundinaceae. They attribute the latter difference to a worse development of the root system of the maize plants in the living mulch system.

Maize plants in the living ryegrass mulch not only showed weaker growth than in the BS plots (Liedgens et al., 2003), they also took up smaller amounts of N. The results are not as consistent as for grain and stover yield, but there is a clear trend towards lower $\mathrm{N}$ concentrations in both components at harvest. Consequently, the $\mathrm{N}$ yield in the maize shoot at harvests was reduced proportionally more than the dry matter yield (Table 3). Wilkinson et al. (1987) also reported lower $\mathrm{N}$ concentrations in maize shoots in controlled Festuca arundinaceae sods, especially at a moderate supply of $\mathrm{N}\left(145 \mathrm{~kg} \mathrm{~N} \mathrm{ha}^{-1}\right)$. Our results are in agreement with the observations made by Feil et al. (1997), showing that the $\mathrm{N}$ concentrations in the maize shoot were lower from the $6^{\text {th }}$ leaf stage onwards in a living Italian ryegrass mulch.

The main reason for the reduced uptake of $\mathrm{N}$ by maize plants was uptake of $\mathrm{N}$ by the grass in the LM plots. In 1994 and 1996 the grass harvested during the crop season and at maize harvest contained almost as much $\mathrm{N}$ as the maize plants harvested in the BS plots (Table 4). In the same years, the maize plants in LM plots accumulated less than $60 \%$ of the $\mathrm{N}$ accumulated by the grass plants. Only in 1995 did the maize plants in the BS plots take up considerably more $\mathrm{N}$ than the grass plants in the LM plots, and the LM maize took up more $\mathrm{N}$ than the grass.

In both systems and in all the years the exported $\mathrm{N}$ was higher than the inputs of fertilizer $\mathrm{N}$. We consider three hypotheses that may explain the high $\mathrm{N}$ availability in the present experiments, which are all related to increased mineralization of organic $\mathrm{N}$ : (i) the soil disturbance caused by the filling of the lysimeters; (ii) higher soil temperatures in the lysimeters placed aboveground, as compared to field soils; (iii) mineralization of $\mathrm{N}$ during the fallow year before the experimental season.

Although the ability of the maize plants to take up $\mathrm{N}$ was considerably affected by the presence of the strips of living Italian ryegrass, the living mulch system was, on the whole, much more efficient in capturing available $\mathrm{N}$ resources than were single stands of maize. This is reflected by the low to very low $\left[\mathrm{NO}_{3}^{-}\right]-$ $\mathrm{SS}$ in the LM plots compared to the BS plots for almost the entire crop season (Figure 5) and at all sampling positions in the soil (Table 3). The low $\left[\mathrm{NO}_{3}^{-}\right]-\mathrm{SS}$ in the LM plots implies that there was only little nitrate in the soil which could have been leached from the soil and this explains the low $\left[\mathrm{NO}_{3}^{-}\right]-\mathrm{L}$ (Figure 3 ) and the negligible losses of $\mathrm{N}$ through leaching in the LM plots (Figure 4 and Table 4).

High levels of $\left[\mathrm{NO}_{3}^{-}\right]-\mathrm{SS}$ throughout the soil profile early in the season and in deep soil layers at later developmental stages of maize in the BS plots (Table 2) are consistent with the patterns of growth of maize roots (Liedgens et al., 2003): root densities reach a maximum around anthesis and are lower in deep compared to shallow soil layers. Even though conventionally cropped maize considerably decreases $\left[\mathrm{NO}_{3}^{-}\right]$-SS during crop growth, the values are very high compared to the LM plots.

As discussed above for soil water contents, the root densities (Liedgens et al., 2003) of the single maize stands do not enable the crop to capture all the available N. High $\left[\mathrm{NO}_{3}^{-}\right]-\mathrm{SS}$ is also found during the crop cycle of maize in the LM plots. However, very low $\left[\mathrm{NO}_{3}^{-}\right]$-L indicates that the established grass roots represent a persistent safety net against $\mathrm{N}$ losses through leaching for the entire growth cycle of the crop.

The systematic reduction in the $\mathrm{N}$ availability over the entire season in the LM plots explains the lower $\mathrm{N}$ uptake and growth of the maize plants. According to Feil et al. (1997) nitrate concentration in the shoot at the $3^{\text {rd }}$ leaf stage is the first symptom of $\mathrm{N}$ deficiency of maize plants in an Italian ryegrass living mulch. Heyland and Werner (1988) also suggested that maize 
may be deficient in $\mathrm{N}$ early in the season, when grown in Lolium perenne or Trifolium repens living mulches.

As the living Italian ryegrass mulch prevents nitrate leaching, an important environmental benefit, the question, thus, remains as to what can be done to improve the growth and yield of maize in this cropping system. Two basic strategies have already been proposed: (i) regulating the growth of the living mulch (Eberlein et al., 1992; Garibay et al., 1997; Kumwenda et al., 1993), (ii) increasing the supply of nitrogen and/or water (Box et al., 1980; Carreker et al., 1972; De Haan et al., 1994; Eberlein et al., 1992; Garibay et al., 1997; Robertson et al., 1976). Under conditions similar to those of the present study, the former strategy implies that less $\mathrm{N}$ will be taken up by the grass plants. This extra $\mathrm{N}$ may be taken up by the maize plants but it is also at risk of being lost by leaching. From the soil water and $\mathrm{N}$ data of the present study and the information on the root systems provided by Liedgens et al. (2003) it must concluded that the root system of the monocropped maize plants is not able to take up all nutrients and water available in the soil. Thus, there is no guarantee that the $\mathrm{N}$ that is not taken up by the grass will be used by the maize plants.

As living mulches decreased maize yields, other alternatives for improving the $\mathrm{N}$ uptake of single maize stands should be considered. Sowing maize in narrow-rows $(0.38$ instead of $0.76 \mathrm{~m})$ at similar plants densities ( 85000 plants $\mathrm{ha}^{-1}$ ) can increase $\mathrm{N}$ uptake by maize, without decreasing yields (Cox and Cherney, 2001). While the reported increase $\left(1.7 \mathrm{~g} \mathrm{~m}^{-2}\right)$ is small compared to the effect of the Italian ryegrass in the present study ( 14.0 to $15.7 \mathrm{~g} \mathrm{~m}^{-2}$ ), it is in the order of magnitude of losses of $\mathrm{N}$ by leaching (1.0 to $2.7 \mathrm{~g} \mathrm{~m}^{-2}$ ).

Increasing the supply of water and $\mathrm{N}$ was shown to improve the yield of the main crop in living mulches, but its implication for leaching is unknown. A negative effect of an increased water supply on $\mathrm{N}$ leaching during the maize crop season is not expected. The comparison of the data sets from 1995 and 1996 show that a greater percolation of water $(+267 \mathrm{~mm}$, Figure 2) was accompanied by a smaller loss of $\mathrm{N}$ $\left(-100 \mathrm{mg} \mathrm{m}^{-2}\right.$, Figure 4) in 1995 in the LM treatment.

Since nitrogen losses in the living mulch system were practically irrelevant in terms of the $\mathrm{N}$ balance it is possible that an increase in the $\mathrm{N}$ supply will not dramatically affect the levels of $\left[\mathrm{NO}_{3}^{-}\right]-\mathrm{L}$. The challenge, however, is to design the cropping system and the schedule of the $\mathrm{N}$ supply in such a way that the $\mathrm{N}$ is primarily available to the maize crop and that the cover crop prevents the loss of $\mathrm{N}$. Increasing the $\mathrm{N}$ supply, however, is undesirable in terms of the current trend towards sustainable agricultural systems and may be difficult to achieve in organic farming systems.

\section{Conclusions}

A living mulch of Italian ryegrass drastically changes the dynamics of water and nitrogen in a maize cropping system. The living mulch reduces the water content between 0.3 and $0.9 \mathrm{~m}$ soil depth. Even intense rainfall is no guarantee that the soil water content in the living mulch system reaches the same level as in a bare soil. The lower soil water contents reduce the excess of water available for deep percolation and the lower $\left[\mathrm{NO}_{3}^{-}\right]-\mathrm{SS}$ prevent high $\left[\mathrm{NO}_{3}^{-}\right]-\mathrm{L}$ resulting in negligible amounts of $\mathrm{N}$ lost through leaching. A decrease in water percolation and in the nitrate concentration in the leachate make the living mulch an environmentally safe cropping system in terms of avoiding contamination of ground water resources. These changes in the dynamics of water and $\mathrm{N}$ explain to a considerable extent the decrease in the growth and yield of the maize plants and are in good agreement with the dense root system developed by the maize - Italian ryegrass mixture at all soil depths compared to the limited root system developed by maize when grown in a bare soil, as described by Liedgens et al. (2003). Reducing the negative impact of the living mulch on the growth and yield of maize without losing the environmental benefit of reduced nitrate leaching will be more likely if the supply of water and $\mathrm{N}$ is increased than if growth of the living mulch is restricted even further. The goal of developing productive and environmentally sound living mulch systems will depend on the ability to improve the efficiency of the root system of maize in taking up nutrients and water in a highly competitive environment without affecting the capacity of the cover crop to function as a safety net for nitrogen at risk of being lost by leaching.

\section{References}

Adams W E, Pallas Jr J E and Dawson R N 1970 Tillage methods for corn-sod systems in the Southern Piedmont. Agron. J. 62, 646-649.

Al Kaisi M, Brun L J and Enz J W 1989 Transpiration and evapotranspiration from maize as related to leaf area index. Agric. Forest Meteo. 48, 111-116. 
Bigler F, Ammon H U, Högger C, Jäggi W, Schubiger F X, Waldburger M, Walther U, Weisskopf P and Fried P M 1995 Vier Maisanbauverfahren 1990 bis 1993. Ökologie und Ökonomie in den Verfahren - eine Bilanz. Agrarforsch. 2, 389-392.

Box Jr J E, Wilkinson S R, Dawson R N and Kozachyn J 1980 Soil water effects on no-till corn production in strip and completely killed mulches. Agron. J. 72, 797-802.

Burman B and Pochop L O 1994 Evaporation, evapotranspiration and climatic data. Elsevier, Amsterdam. 278 pp.

Carreker J R, Box Jr J E, Dawson R N, Beaty E R and Morris H D 1972 No-till corn in fescuegrass. Agron. J. 64, 500-503.

Cox W J and Cherney D J R 2001 Row spacing, plant density, and nitrogen effects on corn silage. Agron. J. 93, 597-602.

De Haan R L, Wyse D L, Ehlke N J, Maxwell B D and Putnam D H 1994 Simulation of spring-seeded smoother plants for weed control in corn (Zea mays). Weed Sci. 42, 35-43.

Duda G P, Guerra J G M, Monteiro M T, De Polli H and Teixeira MG 2003 Perennial herbaceous legumes as live soil mulches and their effects on $\mathrm{C}, \mathrm{N}$ and $\mathrm{P}$ of the microbial biomass. Sci. Agric. 60, 139-147.

Eberlein C V, Sheaffer C C and Oliveira V F 1992 Corn growth and yield in an alfalfa living mulch system. J. Prod. Agric. 5, 332-339.

Enache A J and Ilnicki R D 1990 Weed control by subterranean clover (Trifolium subterraneum) used as a living mulch. Weed Technol. 4, 534-538.

FAL / RAC. 2001. Guidelines for fertilizer use in field and fodder crops 2001. Agrarforsch. 8, 3-80.

Feil B, Garibay S V, Ammon H U and Stamp P 1997 Maize production in a grass mulch system - seasonal patterns of indicators of the nitrogen status of maize. Eur. J Agron. 7, 171-179.

Feil B and Liedgens M 2001 Crop Production in Living Mulches a Review. Pflanzenbauwissenschaften 5, 15-23.

Garibay S V, Stamp P, Ammon H U and Feil B 1997. Yield and quality components of silage maize in killed and live cover crops. Eur. J. Agron. 6, 179-190.

Gibbons J D and Chakraborti S 1992 Nonparametric statistical inference. Marcel Dekker, New York. 544 pp.

Heyland K U and Werner A 1988 The formation of yield and the dynamics of system-conditions in mixed cultivations and their mathematical description with the example of populations consisting of maize and companion-plants. Bodenkultur 39, 233-250.

Kaluli J W, Madramootoo C A, Zhou X M, MacKenzie A F, Smith D L 1999 Subirrigation systems to minimize nitrate leaching. J. Irrig. Drain. Eng. 125, 52-58.

Kumwenda J D T, Radcliffe D E, Hargrove W L and Bridges D C 1993 Reseeding of crimson clover and corn grain yield in a living mulch system. Soil Sci. Soc. Am. J. 57, 517-523.

Kurtz T, Appleman M D and Bray R H 1946 Preliminary trials with intercropping of corn and clover. Soil Sci. Soc. Am. Proc. 11, 349-355.

Kurtz T, Melsted S W and Bray R H 1952 The importance of nitrogen and water in reducing competition between intercrops and corn. Agron. J. 44, 13-17.

Liedgens M, Soldati A and Stamp P 2003 Interactions of maize and Italian ryegrass in a living mulch system: (1) Shoot growth and root patterns. Plant Soil (in press).
Liedgens M, Richner W, Stamp P and Soldati A 2000 A rhizolysimeter facility for studying the dynamics of crop and soil processes: description and evaluation. Plant Soil 223, 87-97.

Littell R C, Milliken G A, Stroup W W and Wolfinger R D 1996 SAS $^{\circledR}$ system for mixed models. SAS Inst., Cary, 633 pp.

Martin R C, Greyson P R and Gordon R 1999 Competition between corn and a living mulch. Can. J. Plant Sci. 79, 579-586.

Nicholson A G and Wien H C 1983 Screening of turfgrasses and clovers for use as living mulches in sweet corn and cabbage. J. Am. Soc. Hort. Sci. 108, 1071-1076.

Ntahimpera N, Ellis M A, Wilson L L and Madden L V 1998 Effects of a cover crop on splash dispersal of Colletotrichum acutatum conidia. Phytopathology 88, 536-543.

Perin A, Guerra J G M, Teixeira M G, Pereira M G and Fontana A 2002 Effect of herbaceous leguminous species as live mulching on soil aggregation. Rev. Bras. Cienc. Solo 26, 713-720.

Rämert, B 1996 The influence of intercropping and mulches on the occurrence of polyphagons predators in carrot flies in relation to carrot fly (Psila rosae (F.)) (Dipt., Psilidae) damage. J. Appl. Ent. 120, 39-46.

Rasse D P, Smucker A J M and Schabenberger O 1999 Modifications of soil nitrogen pools in response to alfalfa root systems and shoot mulch. Agron. J. 91, 471-477.

Robertson W K, Lundy H W, Prine G M and Currey W L 1976 Planting corn in sod and small grain residues with minimum tillage. Agron. J. 68, 271-274.

Rüttimann M 2001 Boden-, Herbizid- und Nährstoffverluste durch Abschwemmung bei konservierender Bodenbearbeitung und Mulchsaat von Silomais. Physiogeographica 30. Basel, 241 pp.

Sato S, Tateno K, Kobayashi R and Sakamoto K 1999 Effect of sowing date and living mulch on the growth of velvetleaf (Abutilon theophrasti Medic.) in forage corn (Zea mays L.). Grass. Sci. 44, 374-377.

Teasdale J R 1996 Contribution of cover crops to weed management in sustainable agricultural systems. J. Prod. Agric. 9, 475-479.

Tolk J A, Howell T A and Evett S R 1999 Effect of mulch, irrigation, and soil type on water use and yield of maize. Soil Tillage Res. 50, 137-147.

Topp G C, Davis J L and Annan A P 1980 Electromagnetic determination of soil water content: Measurement in coaxial transmission lines. Wat. Resour. Res. 16, 574-582.

Venables W N and Ripley B D 2002 Modern Applied Statistics with S. Springer, New York. 495 pp.

Weston L A 1996 Utilization of allelopathy for weed management in agroecosystems. Agron. J. 88, 860-866.

Wilkinson S R, Devine O J, Belesky D P, Dobson Jr J W and Dawson R N 1987 No-tillage intercropped corn production in tall fescue sod as affected by sod-control and nitrogen fertilization. Agron. J. 79, 685-690.

Zemenchik R A, Albrecht K A, Boerboom C M and Lauer J G 2000 Corn production with kura clover as a living mulch. Agron. J. 92, 698-705.

Section editor: $Y-G$. Zhu 